\title{
PCNA AND P53 EXPRESSION IN ORAL LEUKOPLAKIA WITH DIFFERENT DEGREES OF KERATINIZATION
}

\author{
EXPRESSÃO DO PCNA E P53 EM LEUCOPLASIAS DE MUCOSA JUGAL COM DIFERENTES \\ GRAUS DE QUERATINIZAÇÃO
}

Melaine de Almeida LAWALL ${ }^{1}$, Marcelo Macedo CRIVELINI ${ }^{2}$

1- DDS, MSc, Graduate Student, Department of Oral Pathology, Dental School, State University, Araçatuba, São Paulo, Brazil.

2- DDS, MSc, PhD, Associate Professor, Department of Oral Pathology, Dental School, State University, Araçatuba, São Paulo, Brazil.

Corresponding address: Rua São Gonçalo, nº6-73. Vila Altinópolis - Bauru - SP - Cep.: 17012-170 - Telephone number: (14) 3234-6120

Cel phone: (14) 9735-8727 - e-mail address: melainelawall@yahoo.com.br

Received: March 07, 2006 - Modification: June 01, 2006 - Accepted: June 14, 2006

\begin{abstract}
$L$

eukoplakias are oral lesions that may have many clinical and histological aspects and they are usually associated with malignancy when dysplastic alterations are shown. However, these transformations may occur in non-dysplastic lesions that show harmless clinical aspect. For this reason, the proposal was to study the p53 and PCNA immunohistochemical expression in non-dysplastic leukoplakias, trying to correlate the results only with the epithelial keratinization degree. For this, 24 leukoplakias degrees I, II and III of Grinspan were used, all of them located in oral mucosa. Most of the leukoplakias showed p53 and PCNA expression in their different keratinization degrees. The p53 marking was confined to the basal and parabasal layers, while the PCNA marking occurred in practically all epithelial layers. The expression pattern of these markers was histologically and statistically similar between the lesions with these keratinization variations. It was evident that non-dysplastic epithelium of leukoplakias showed submicroscopical signs of alterations that lead to malignant transformation, and that the keratinization degree did not correlate to a greater risk of this event.

Uniterms: Leukoplakia; Immunohistochemistry; p53; Proliferating cell nuclear antigen (PCNA).
\end{abstract}

\section{RESUMO}

A

s leucoplasias são lesões orais que podem apresentar vários aspectos clínicos e histológicos e são associadas à malignidade geralmente quando apresentam alterações displásicas. Contudo, essas transformações podem ocorrer em lesões sem displasia que apresentam aspecto clínico inocente. Por esse motivo nossa proposta foi estudar a expressão imuno-histoquímica do p53 e PCNA em leucoplasias sem displasias, buscando correlacionar os resultados apenas com o grau de queratinização epitelial. Para isso foram utilizadas as leucoplasias Grau I, II e III de Grinspan, num total de 24 lesões, todas localizadas em mucosa jugal. A maior parte das leucoplasias, em seus diferentes graus de queratinização, apresentou expressão de p53 e PCNA. A marcação do p53 restringiu-se às camadas basal e parabasal, enquanto a do PCNA ocorreu em praticamente todas as camadas epiteliais. O padrão de expressão desses marcadores foi histologicamente e estatisticamente semelhante entre as lesões com esta variação de queratinização. Ficou evidente que os epitélios não displásicos das leucoplasias possuem sinais sub-microscópicos de alterações direcionadas à transformação maligna e o grau de queratinização não se correlacionou ao maior risco desse acontecimento.

Unitermos: Leucoplasia; Imuno-histoquímica; p53; Antígeno nuclear de proliferação celular (PCNA). 


\section{INTRODUCTION}

Oral leukoplakias are admittedly premalignant lesions. Many authors relate dysplastic alterations to a higher tendency of these lesions for malignant transformations. However, due to the subjectivity of dysplasia analysis and to the possibility of non-dysplastic leukoplakias to develop malignancy, there has been a need to develop other criteria, more specifically to predict the malignant potential of these lesions, such as immunohistochemistry (Bánóczy³, 1977; Pindborg, et al. ${ }^{18}$, 1985; Burkhardt ${ }^{7}$, 1985; Karabulut, et al. ${ }^{14}$, 1995; Axéll, et al. ${ }^{2}$, 1996; Van Der Waal ${ }^{28}$, 1997; Wright ${ }^{30}$, 1998; Schepman, et al. ${ }^{23}$, 1998; Warnakulasuriya ${ }^{29}$, 2000).

Mutations in the p53 tumor suppressor gene are among the most frequent genetic alterations associated to human cancer and they result in a more stable genetic product, which is detected by immunohistochemistry. Therefore, it could be used as an indirect indicator of these alterations. The gradual growing expression of the $\mathrm{p} 53$ protein, following the tissue progression from normal epithelium to hyperplasia, to dysplasia and to carcinoma, supports the concept of the multistep process of tumorigenesis in the head and neck region. It can suggest that p53 alterations might be a useful biomarker in assessing risk of cancer development in normal tissue and premalignant lesions exposed to carcinogenic agents (Bennett, et al. ${ }^{4}$, 1991; Shin, et al..$^{25}$, 1994; Greenblatt, et al. ${ }^{11}$, 1994; Saranath, et al..$^{21}$, 1999; Saito, et al. ${ }^{20}$, 1999).

Proliferating cell nuclear antigen (PCNA) is an acidic intranuclear 36-kd polypeptide linked to cell cycle. Its distribution in the cell cycle increases during the G1-phase, peaks at the G1/S-phase interface, and decreases through the G2-phase, reaching low levels which are virtually undetectable by immunohistochemical methods in the Mphase and quiescent cells. As PCNA is detected in its peak distribution, it can be a useful marker for proliferating cells (Celis and Celis ${ }^{9}$, 1985; Kurki, et al. ${ }^{16}$, 1988; Tsai and Jin ${ }^{26}$, 1995).

PCNA expression pattern can also be helpful in the comprehension of the process of tumorigenesis, since there is a gradual increase in terms of the number of PCNA-positive cells with the progress from normal epithelium to malignancy. Furthermore, the distribution of PCNA-positive cells in the basal and parabasal layers in the normal epithelium and benign lesions, and the distribution of PCNA-positive cells in the suprabasal layers in dysplasias, carcinomas in situ, and invasive carcinomas demonstrate that early dysplastic alterations may occur without the histopathological signs seen by optical microscopy through conventional histochemical methods (Shin, et al. ${ }^{24}$, 1993; Shin, et al. ${ }^{25}$, 1994; Huang, et al. ${ }^{13}$, 1994; Tsuji, et al. ${ }^{27}$, 1995; MartinezLara, et al. ${ }^{17}$, 1996).

Inasmuch as oral leukoplakias with innocent aspect can also undergo malignant transformation independently of their localization, the goal of this work was to assess the epithelial proliferative activity of non-dysplastic leukoplakias outside the areas of higher risk of malignant transformation through PCNA and p53 immunohistochemistry detection, and correlate the results with the amount of keratin produced by the lesion. The quantification of keratin followed the clinical and pathological criteria of Grinspan ${ }^{12}$ (1973) where Degree I represents leukoplakia spots with discrete hyperkeratosis, Degree II represents white plates showing hyperkeratosis, and Degree III represents white plates and verrucosis, with hyperkeratosis and papillomatosis.

\section{MATERIALAND METHODS}

The materials consisted of 24 leukoplakias retrieved from the files of the Histopathology Service of the Pathology and Clinical Propedeutics Department of Araçatuba Dental School, Brazil. These leukoplakias were graded and separated in three groups following Grinspan's criteria ${ }^{12}$ (1973): 8 degree I leukoplakias, 8 degree II leukoplakias, and 8 degree III leukoplakias.

Tissue sections of $4 \mu \mathrm{m}$ were used for immunohistochemical staining. The sections were dewaxed in xylene and rehydrated in graded ethanol according to standard procedures. Antigen retrieval was obtained by treating the sections with citric acid (10 mM, 6.0 pH), three times for $4 \mathrm{~min}$, at $900 \mathrm{~W}$ in microwave oven. The endogenous peroxidase was blocked with methanol and hydrogen peroxide $\mathrm{H}_{2} \mathrm{O}_{2}(1: 1, \mathrm{v} / \mathrm{v})$ for $10 \mathrm{~min}$.

The sections were incubated with primary antibodies according to the data in Table 1. Then they were incubated with secondary antibody for $30 \mathrm{~min}$ at room temperature and finally incubated with Streptavidin-Biotin Complex for $30 \mathrm{~min}$ at room temperature. The $0.03 \%$ diaminobenzidine solution containing $0.6 \mathrm{~mL}$ of hydrogen peroxide was used to visualize the peroxidase activity. After that, the slides were lightly counterstained with Mayer's hematoxylin.

The positive control was squamous cell carcinoma with a known pattern. The negative control consisted of the replacement of the primary antibody for $1 \%$ bovine serum albumin, diluted in phosphate saline solution (TRIS, pH 7.4). Sections of $6 \mu \mathrm{m}$ were stained with methanamine silver to

TABLE 1- Monoclonal antibodies used

\begin{tabular}{llll}
\hline Antibodies & Clone & Dilution & Incubation Time \\
\hline PCNA* $^{*}$ & PC-10 & $1: 600$ & Overnight \\
P53 & DO-7 & $1: 75$ & Overnight \\
\hline
\end{tabular}

* Dako Corporation, Carpinteria 
verify the presence of Candida.

To assess the amount and distribution of PCNA and p53 expression on the immunostained slides, the expression of the biomarker on digitized images was quantified using Leica Qwin Image System (Image Processing and Analysis Sistem), attached to a Leica microscope. The quantitative evaluation involved visual identification of stained nuclei, and manual circling of each nucleus with a light pen under high-power microscopy (objective lens x 400), on a randomly selected area of approximately 19,500 $\mu \mathrm{m}$. These data were submitted to statistical analysis.

\section{RESULTS}

\section{p53}

The p53 expression was observed in all groups. In degree I, few p53-positive cells were observed in the basal and parabasal cell layers in 5 sections (Figure 1), and 3 sections were p53-negative. Six of the 8 sections of degree II showed p53-positive cells in the basal and parabasal layers, while 2 sections showed p53-positive cells only in the basal layer. In degree III, 2 sections showed few p53-positive cells in the basal and parabasal layers, 4 sections showed few p53positive cells in the basal layer, and 2 sections did not show p53-positive cells. Subjectively, p53 expression was higher in degrees I and II. The score of p53-positive cells is in Table 2.

\section{PCNA}

PCNA-positive cells were observed in the basal and parabasal layers in all 8 sections in degree I, and 7 of those sections also presented many positive cells in the suprabasal layers. The degree II sections presented the same expression as degree I sections, with PCNA-positive cells in the basal, parabasal and suprabasal layers. In degree III, 7 sections showed PCNA-positive cells in the basal and parabasal layers (Figure 2) and 1 section showed PCNA-positive cells in the suprabasal layer, too. Subjectively, PCNA expression was higher in degrees I and II. PCNA-positive cells score is in Table 3.

Statistical analysis was performed using one-way analysis of variance for the number of stained cells. Statistical difference was not observed concerning the number of p53positive ( $\mathrm{P}=12.713 \%)$ among the three degrees. For PCNA, there was no statistically significant difference either $(\mathrm{P}=5.599 \%)$. However, because of the large difference shown between the average of stained cells in degrees I and III (130, 37), the Tukey Test was performed and revealed the critical value of 139.89 at the $5 \%$ level. The result allowed us to infer that there was a tendency for degree I to show a higher number of stained cells than degree III, if the number of sections were greater.

\section{DISCUSSION}

It has been considered that leukoplakias can show higher or lower risk of malignant transformation depending on their localization in oral mucosa, being the most dangerous the ones located on floor of the mouth and tongue. Many authors quote the oral mucosa as an area of higher incidence of leukoplakias; however, this area presents low risk of malignant transformation (Áxell ${ }^{1}$, 1984; Bouquot and Gorlin ${ }^{6}$, 1986). Thus, the lesions located in oral mucosa were studied, avoiding epithelial dysplasias or microscopic malignant alterations.

Although Candida was connected to the etiology of leukoplakias (Bánóczy ${ }^{3}$, 1977); we decided not to include leukoplakias with Candida in this work to avoid the incidental influence of the fungus in the p53 and PCNA immunohistochemical expression. Nevertheless, the fungus was seen in all 8 sections of leukoplakias of degree III. Those lesions could not be discarded because of the limited number of samples. This finding raised the distrust that the fungus was responsible for some of the alterations found in the epithelium such as papillomatosis, in accordance with Kollar et al. ${ }^{15}$ (1954), or verrucoid leukoplakias (Degree III) favor opportunist infections by Candida. Lesions degrees I and II did not present fungus in the histochemical analysis.

The subjectivity in the analysis of dysplastic alterations in leukoplakias makes this criterion fallible to predict the malignant potential of these lesions. Furthermore, the

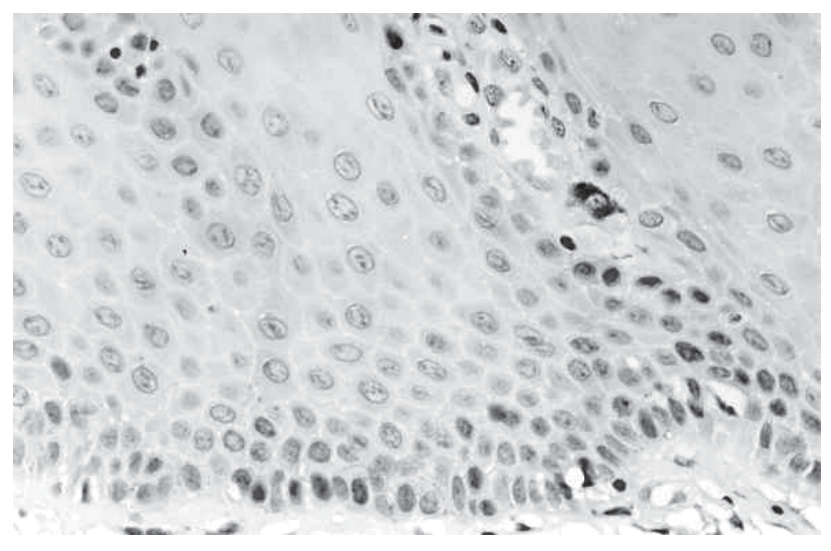

FIGURE 1- Leukoplakia degree I. p53-positive cells in basal and parabasal layers (original magnification: X400)

TABLE 2- p53-positive cells score (Area: 19,500 $\mu \mathrm{m}$. Original magnification $\times 400$ )

\begin{tabular}{llll}
\hline Sections & Degree I & Degree II & Degree III \\
\hline 1 & 13 & 8 & 0 \\
2 & 9 & 38 & 0 \\
3 & 8 & 6 & 16 \\
4 & 18 & 53 & 17 \\
5 & 10 & 8 & 8 \\
6 & 0 & 49 & 22 \\
7 & 0 & 14 & 9 \\
8 & 0 & 1 & 4 \\
\hline
\end{tabular}


presence of dysplasia does not always indicate malignant transformation, and its absence does not prevent the malignant transformation from occurring. All this, added to the fact that leukoplakias without dysplastic alterations may develop malignant transformation with time, makes it necessary to use a new criterion to predict alterations of this kind (Karabulut, et al. ${ }^{14}$, 1995; Áxell, et al. ${ }^{2}$, 1996; Van Der Wall, et al. ${ }^{28}$, 1997; Schepman, et al. ${ }^{23}$, 1998; Cruz, et al. ${ }^{10}$, 1998; Warnakulasuriya ${ }^{29}$, 2000).

We looked for a biomarker of the potential of malignancy of leukoplakias using p53 and PCNA through immunohistochemistry, with attention to hyperkeratosis. These biomarkers can show signs of malignant alterations that are not microscopically visible with the conventional histochemical methods in the epithelium of morphologically normal leukoplakias.

According to the present results, there was no statistically significant difference between the p53 expression in the three groups. It makes us believe that the difference in degree of keratinization cannot be considered as a significant datum to predict the malignant potential of these lesions, at least in the study on this protein. However, comparing them with the normal epithelium, which, according to the literature, practically does not express this protein, the frequency of detection was higher.

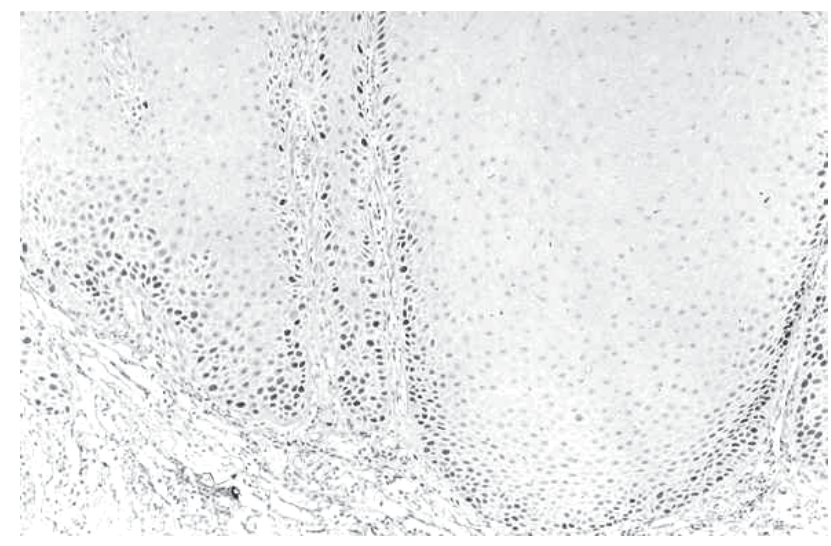

FIGURE 2- Leukoplakia degree III. PCNA-positive cells in basal and parabasal layers (original magnification: X100).

TABLE 3- PCNA-positive cells score (Area: 19,500 $\mu \mathrm{m}$. Original magnification $\times$ 400)

\begin{tabular}{llll}
\hline Sections & Degree I & Degree II & Degree III \\
\hline 1 & 366 & 201 & 34 \\
2 & 193 & 387 & 145 \\
3 & 344 & 256 & 374 \\
4 & 104 & 267 & 66 \\
5 & 365 & 290 & 237 \\
6 & 345 & 340 & 146 \\
7 & 559 & 279 & 164 \\
8 & 218 & 280 & 285 \\
\hline
\end{tabular}

Alterations in gene p53 seem to be initial events in the oral carcinogenesis, occurring before coarse phenotypic alterations (Regezi, et al. ${ }^{19}$, 1995; Cruz, et al. ${ }^{10}$, 1998). This could justify the p53 protein parabasal expression seen in the sections of non-dysplastic leukoplakias. Moreover, it corroborates our suspicions that signs of malignant alterations that are not microscopically visible with the conventional histochemical methods in the morphologically normal epithelium of leukoplakias can occur before the morphological alterations are detected. The gradual rise of p53 protein expression following the tissue progress from normal epithelium to hyperplasia, to dysplasia, and to carcinoma is known (Shin, et al. ${ }^{25}$, 1994; Sauter, et al. ${ }^{22}$, 1994). Inasmuch as a higher number of stained cells was found in leukoplakias than the literature describes in the normal oral epithelium, this could be an indication of the sequential process of tumorigenesis (Saito, et al. ${ }^{20}, 1999$ ).

Despite the variation in the PCNA expression, the difference between the 3 groups was not statistically significant. The degree of keratinization of the leukoplakias could not be related to higher or lower cell proliferative activity. However, we suspect that the degree III lesions, with papillomatosis, are more innocent than the degree I and II lesions. Hence, the suspicion that verrucous lesions with acanthosis had higher chances of developing malignant transformation (Castro ${ }^{8}$, 2000) was not verified with these biomarkers.

Martinez-Lara, et al. ${ }^{17}$ (1996) suggested that PCNA suprabasal expression could work as a marker in initial dysplasias, without histological signs. This can justify the PCNA expression in suprabasal keratinocytes seen in the sections and corroborate our doubt that there are signs of malignant alterations in the morphologically normal epithelium of leukoplakias that are not microscopically visible with the conventional histochemical methods, and they occur before the morphological alterations are detected. Furthermore, this pattern of PCNA expression could demonstrate evidence of malignancy or relation with DNA repair (Huang, et al. ${ }^{13}$, 1994; Birchall, et al. ${ }^{5}$, 1997).

\section{CONCLUSIONS}

Thus, it may be conclude that the leukoplakias without epithelial dysplasia present a different epithelium, in a worrying morbid state, with biochemical but without morphological alterations. This factor is already sufficient to reinforce the real clinical meaning of leukoplakia, which should not be interpreted as a simple hyperkeratotic alteration of the oral mucosa, but might be seen as a potentially dangerous lesion. By the way, the results confirm what the clinical experience had already shown about the caution of the clinician with this kind of lesions. However, it is still impossible to obtain more accurate information about the higher or lower risk of malignant transformation using these biomarkers. Apparently, the amount of keratin does not influence the risk of malignant transformation of nondysplastic leukoplakias of oral mucosa. 


\section{ACKNOWLEDGEMENTS}

Fundação de Amparo à Pesquisa do Estado de São Paulo (FAPESP)-Processo n ${ }^{\circ}$ 01/03928-7

\section{REFERENCES}

1- Axéll T, Holmstrup P, Kramer IR, Pindborg JJ, Shear M. International seminar on oral leukoplakia and associated lesions related to tobacco habits: Lund University, Malmo, Sweden, June 27-30. Community Dent Oral Epidemiol.1984;12:145-54.

2- Axéll T, Pindborg JJ, Smith CJ, van der Waal I. Oral white lesions with special reference to precancerous and tobacco-related lesions: conclusions of an international symposium held in Uppsala, Sweden, 18-21 1994. J Oral Pathol Med. 1996;25(2):49-54.

3- Bánóczy J. Follow-up studies in oral leukoplakia. J Maxillofac Surg. 1977;5(1):69-75.

4- Bennett WP, Hollstein MC, He A, Zhu SM, Resau JH, Trump BF, et al. Archival analysis of p53 genetic and protein alterations in chinese esophageal cancer. Oncogene. 1991;6(10):1779-84.

5- Birchall MA, Schock E, Harmon BV, Gobe G. Apoptosis, mitosis, PCNA and bcl-2 in normal, leukoplakic and malignant epithelia of human oral cavity: prospective, in vivo study. Oral Oncol. 1997;33(6):419-25.

6- Bouquot JE, Gorlin, RJ. Leukoplakia, lichen planus, and other oral keratoses in 23,616 white Americans over the age of 35 years. Oral Surg Oral Med Oral Pathol. 1986;61(4):373-81.

7- Burkhardt A. Advanced methods in the evaluation of premalignant lesions and carcinomas of the oral mucosa. J Oral Pathol. 1985;14(10):751-78.

8- Castro AL. Estomatologia. São Paulo: Ed Santos; 2000.

9- Celis JE, Celis A. Cell cycle-dependent variations in the distribution of the nuclear protein cyclin proliferating cell nuclear antigen in cultured cells: subdivision of $\mathrm{S}$ phase. Proc Natl Acad Sci. 1985;82(10):3262-6

10- Cruz IB, Snijders PJ, Meijer CJ, Braakhuis BJ, Snow GB Walboomers JM, et al. p53 expression above the basal cell layer in oral mucosa is an early event of malignant transformation and has predictive value for developing oral squamous cell carcinoma. J Pathol. 1998;184(4):360-8.

11- Greenblatt MS, Bennett WP, Hollstein M, Harris CC. Mutations in the p53 tumor supressor gene: clues to cancer etiology and molecular pathogenesis. Cancer Res. 1994;54(18):4855-78.

12- Grinspan D. Enfermidades propias de las mucosas. In: Enfermidades de la boca: semiologia, patologia, clinica y terapeutica de la mucosa bucal. Buenos Aires: Mundi; 1973. p. 1465-517.

13- Huang WY, Coltrera M, Schubert M, Morton T, Truelove E. Histopathologic evaluation of proliferating cell nuclear antigen (PC10) in oral epithelial hyperplasias and premalignant lesions. Oral Surg Oral Med Oral Pathol. 1994;78(6):748-54.

14- Karabulut A, Reibel J, Therkildsen MH, Praetorius F, Nielsen HW, Dabelsteen E. Observer variability in the histologic assessment of oral premalignant lesions. J Oral Pathol Med. 1995;24(5):198200 .

15- Kollar JA, Finley CW, Nabers JM, Ritchey B, Orban BJ. Leukoplakia. J Am Dent Assoc. 1954;49(5):538-48.
16- Kurki P, Ogata K, Tan EM. Monoclonal antibodies to proliferating cell nuclear antigen (PCNA)/cyclin as probes for proliferating cells by immunofluorescence microscopy and flow cytometry. J Immunol Methods. 1988;109(1):49-59.

17- Martinez-Lara I, Gonzalez-Moles MA, Ruiz-Avila I, Bravo M, Ramos MC, Fernandez-Martinez JA. Proliferating cell nuclear antigen (PCNA) as a marker of dysplasia in oral mucosa. Acta Stomatol Belg. 1996;93(1):29-32.

18- Pindborg JJ , Reibel J, Holmstrup B. Subjectivity in evaluating oral epithelial dysplasia, carcinoma in situ and initial carcinoma. J Oral Pathol. 1985;14(9):698-708.

19- Regezi JA, Zarbo RJ, Regev E, Pisanty S, Silverman S, Gazit D. p53 protein expression in sequencial biopsis of oral dysplasias and in situ carcinomas. J Oral Pathol Med. 1995;24(1):18-22.

20- Saito T, Nakajima T, Mogi K. Immunohistochemical analysis of cell cycle-associated proteins p16, pRb, p53, p27 and Ki67 in oral cancer and precancer with special reference to verrucous carcinomas. J Oral Pathol Med. 1999;28(5):226-32.

21- Saranath D, Tandle AT, Teni TR, Dedhia PM, Borges AM, Parikh $\mathrm{D}$, et al. p53 inactivation in chewing tobacco-induced oral cancers and leukoplakias from India. Oral Oncol. 1999;35(3):242-50.

22- Sauter ER, Cleveland D, Trock B, Ridge JA, Klein-Szanto AJ. p53 is overexpressed in fifty percent of pre-invasive lesions of head and neck epithelium. Carcinogenesis. 1994;15(10):2269-74.

23- Schepman KP, van der Meij EH, Smeele LE, van der Waal I. Malignant transformation of oral leukoplakia: a follow-up study of a hospital-based population of 166 patients with oral leukoplakia from the Netherlands. Oral Oncol. 1998;34(4):270-5.

24- Shin DM, Voravud N, Ro JY, Lee JS, Hong WK, Hittelman WN. Sequencial increases in proliferating cell nuclear antigen expression in head and neck tumorigenesis: a potencial biomarker. J Nat Cancer Inst. 1993;85(12):971-8.

25- Shin DM, Kim J, Ro JY, Hittelman J, Roth JA, Hong WK, et al. Activation of p53 gene expression in premalignant lesions during head and neck tumorigenesis. Cancer Res. 1994;54(2): 321-6.

26- Tsai ST, Jin YT. Proliferating cell nuclear antigen (PCNA) in oral squamous cell carcinomas. J Oral Pathol Med. 1995;24(7):3135

27- Tsuji T, Mimura Y, Wen S, Li X, Kanekawa A, Sasaki K, et al. The significance of PCNA and p53 protein in some oral tumors. Int J Oral Maxillofac Surg. 1995;24(3):221-5.

28- van der Wall I, Schepman KP, van der Meij EH, Smeele LE. Oral leukoplakia: a clinicopathological review. Oral Oncol. 1997;33(5):291-301.

29- Warnakulasuriya S. Lack of molecular markers to predict malignant potencial of oral precancer. J Pathol. 2000;190(4):407-9.

30- Wright JM. A review and update of oral precancerous lesions. Tex Dent J. 1998;115(6):15-9. 